\title{
Intramammary Lymph Node
}

National Cancer Institute

\section{Source}

National Cancer Institute. Intramammary Lymph Node. NCI Thesaurus. Code C137678.

Any of the lymph nodes located within the breast parenchyma. 